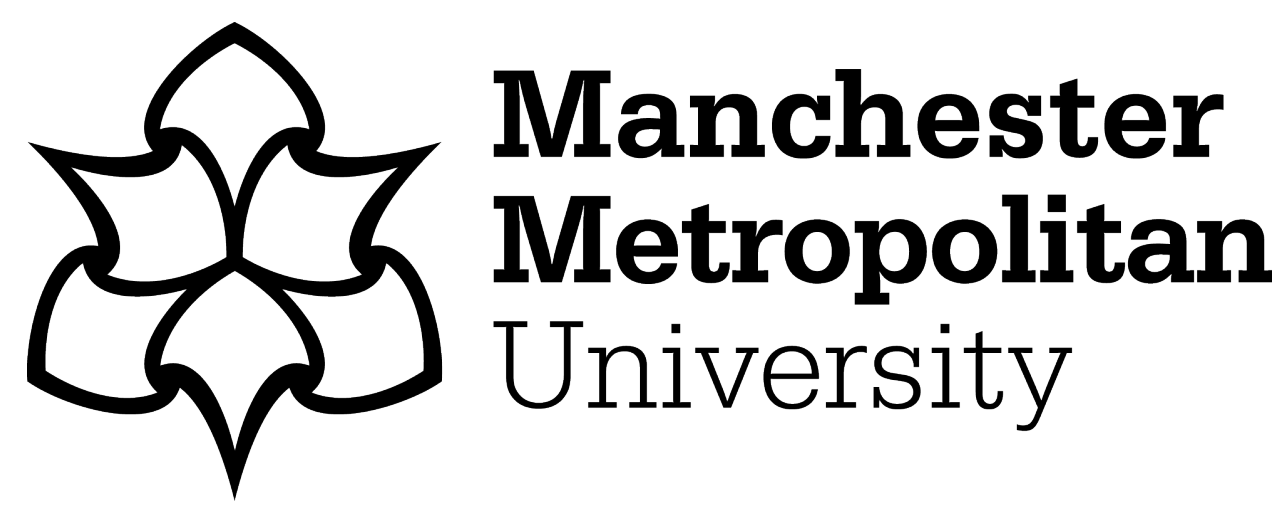

Cardoso, D ORCID logoORCID: https://orcid.org/0000-0001-7864-7531 (2017) Gazing upon the (disgusted) gaze: the abnormal regulation of 'normal' sexuality. Porn Studies, 4 (4). pp. 468-472. ISSN 2326-8743

Downloaded from: https://e-space.mmu.ac.uk/624055/

Version: Accepted Version

Publisher: Taylor \& Francis

DOI: https://doi.org/10.1080/23268743.2017.1398678

Please cite the published version 


\section{Gazing upon the (disgusted) gaze: The abnormal regulation of 'normal'}

sexuality

Daniel Cardoso - ECATI-ULHT, FCSH-UNL

It is challenging to describe the transnational internet phenomenon known as "2 Girls, 1 Cup" (2G1C) in a language that would suit an academic context. To the benefit of all those who haven't yet seen the video clip, I have earlier summed it up as a famous online pornographic video that starts with two women kissing and then cuts directly to explicit and literally scatological interaction between them.

In my own research involving interviews with 11 Portuguese youngsters on their uses of new media in contexts relating to sexuality and gender (17-20-year-olds), several mentioned interacting with $2 \mathrm{G} 1 \mathrm{C}$, either by themselves or when asked about it, and always describing group interactions. Later in the text, I will delve deeper into these testimonies and what they can tell us about the social usages of $2 \mathrm{G} 1 \mathrm{C}$. I would nevertheless like to start this essay by commenting on my own short definition of the video through the lens of the attention that several media outlets (Declercq 2017; Klee 2017) have given to this internet meme on its tenth anniversary.

The most evident doubt that my definition raises is the use of "literal" - if cinema plays with our perception of reality, then real and realism are separate, and thus the images themselves cannot attest to the veracity of the material used in the filming. But, as we see in the two news pieces cited above, this question of authenticity is central to the concerns that (might) interest the readers and that the journalists use to create narrative tension - were actual feces used? Likewise, authenticity has been discussed elsewhere 
as having both promises and pitfalls, within the wider context of gendered and sexual discrimination (van Doorn 2010; Webber 2013; Young 2014). This concern with authentic - rather than realistic - experiences speaks to a seemingly strong desire to be moved or affected by things themselves, so that our carnal resonance (Paasonen 2011b) is not somehow 'deceived'.

The phenomenon of $2 \mathrm{G} 1 \mathrm{C}$ is a clear demonstration that pornography - however and whenever we define pornography (Attwood 2002, 2011) - is not solely linked to pleasure, masturbation or arousal, but rather to a plethora of different carnal resonances, including disgust (Scarcelli 2015). In fact, this dimension of disgust seems to be what draws viewers - willing or otherwise - to 2G1C, as Susanna Paasonen (2011a) explores at length, even questioning 2G1C's status as pornography in several contexts where it is visualized. Declercq (2017) argues that $2 \mathrm{G} 1 \mathrm{C}$ was "the inventor of the reaction video on YouTube" (another memetic category of content that has to do with recording people's reactions to certain materials); regardless of how accurate this assertion might be, the fact is that a search on Google Scholar with the expression "2 Girls, 1 Cup" in any language produces a mere 83 results (does this put into question the role of $2 \mathrm{G} 1 \mathrm{C}$ on cyberculture, or does it say something about the normalization implied and operated by how research is conducted, as Jones \& Mowlabocus (2009) argue?), several of which are from the area of film studies, and focus on how reaction videos operate, rather than on how $2 \mathrm{G} 1 \mathrm{C}$ operates as a filmic object in itself, while others focus on obscenity laws and its complicated relationship to the internet's porous borders.

As Paasonen clearly shows in her opening piece (this volume), social media have given $2 \mathrm{G} 1 \mathrm{C}$, and other such videos, a very peculiar dynamics of circulation and meaning- 
making, thus opening up a field of polysemy for deploying and responding to such content. To show them is to elicit responses - and several become possible but, in the end, only a few are deemed normal or proper.

This framing of $2 \mathrm{G} 1 \mathrm{C}$ as a motor for reacting is what Paasonen (2010) talks about when she mentions how "people express disgust, hide their faces, turn away from the screen [...]" and then "reaction videos are exchanged, new people are invited to make theirs, affective reactions related to the original viral video become social". I concur with Paasonen's analysis that Ahmed's (2014) work of looking at emotions as cultural, as having geographical circulation and varying intensities is fundamental but, having set up this framework, I would like to turn my attention to the local aspects of this circulation. So, rather than look at how the internet promotes cultures of sharing and amplifies certain cultural products beyond the scope of their production or even of their intended targets - here, a short video clip intended to promote a full-feature pornographic movie produced in Brazil ends up as an international internet sensation almost wholly disconnected from the original movie - I want to reflect on the privatized, but still social, usages of this material, on what localized power dynamics are made possible. The existence of the disgusting or the shocking operates, I argue, as an affective and cognitive nexus of Othering that allows for the continued policing of the line between 'good' and 'bad' sexuality (Rubin 2007) via (what are seen to be) prediscursive reactions.

As other research has shown (e.g.: Steven Jones 2009), much of this involves a form of pranking - users are unwittingly invited to view $2 \mathrm{G} 1 \mathrm{C}$ without knowing or being able to 
control the situation, and will often respond by laughing which, according to Jones (idem: 129) "can arise from being affronted or from causing offence to others". Yet, this dynamic was wholly transparent to my interviewees - they themselves reported that $2 \mathrm{G} 1 \mathrm{C}$ "is used to discover what kind of reaction people will have to it" [Subject $A^{1}$, woman, 20 years old]. Subject $A$ then listed all the possible reactions that occurred to her at the time: "[...] if it's shock, if it's horror, if it's disgust, if it's [laughs] all that at once". Only negative reactions seem possible or expectable, creating a horizon of expectations that, as we'll see, has normative implications.

Some even challenged the idea that there was any kind of affront or offence: "I remember a colleague of mine sitting me down in a chair and making me watch [2G1C], mocking me... and I laughed out loud, it was so stupid! [...] Even I did it afterwards to other people and I didn't mind at all [...] Oh, no, no one ever got upset because of it!" [Íris, woman, 18 years old]. Even for those who talked about being bothered (or rather, knowing someone who was bothered), they do so by creating a very clear line between themselves and others: "Oh, fine, some people get off on that, man, but I think it's disgusting. [...] Obviously, there's room for everyone. But only as long as I'm not part of it" [Redgi, woman, 19 years old]. In this case, a self-presenting "gay woman", Redgi, was having difficulties in being inclusive and, at the same time, distancing herself from those acts (along with golden showers, spitting, and others).

Joana [woman, 19 years old] talks about not having seen $2 \mathrm{G} 1 \mathrm{C}$, but being pressured by others: "It was, kind of, peer pressure, right?... and I, uhm, didn't care for it. [...] But in the case of $2 \mathrm{G} 1 \mathrm{C}$, I don't think there was a single person who liked it, there's even

\footnotetext{
${ }^{1}$ All the aliases where chosen by the interviewees themselves.
} 
those reaction videos online [...] so I just built up my own idea of what it was, and knew it didn't interest me". At the same time, Joana says that people will ordinarily look at things online that they already know they don't like, because people need to "know both sides of the issue" and "you can't criticize without knowing what you're talking about". This reinforces a moral obligation to see without wanting, and thus normalizes coercive and non-consensual acts (such as the 'prank' of showing someone 2G1C).

What I think that is missing in looking at this laughter and offence-causing is a deeper look into the power dynamics involved at the microphysical level, to borrow from Michel Foucault (2013). Either laughter or disgust express the same thing: the distancing that Paasonen mentions, but not only from the material being viewed, and rather from the whole category of sexuality for which it stands - the Other, the abnormal, the 'extreme', the non-genital, the 'pathological'. This social setting mobilizes $2 \mathrm{G} 1 \mathrm{C}$ to produce a normal sexuality by evoking a distancing from the abnormal sexuality. Foucault talks about how technologies of the self are ways for the individual to make themselves into a proper subject (Foucault 2000a), which requires a continual self-revisal and the enacting of operations over the self, of self-testing and self-proving, in a moral process which produces that proper subject in continuity (Foucault 1994b). Part of this comes from models that are enforced by society and specific social groups (Foucault 2000b, 291). The governmentality of the self and of others involves a series of "practices that constitute, define, organize and instrumentalize strategies" $(2000 \mathrm{~b}, 300)$ in social settings. Making others look at 2G1C is, I argue, one such strategy - it enacts a power dynamics between the person who is showing the video and the person to whom it is being shown, and places the latter under 
the moral obligation to react in a proper way to attest the 'correct' construction of their own sexuality as immanent and immediate (Foucault 1994a).

A good way to demonstrate this point is to mention, again, an interviewee of mine, who gave an example about a 'wrong' deployment of disgust. Subject $A$ told me that she, and male friends of hers, showed a female friend images of "an outie labia" ${ }^{\text {. That friend }}$ reportedly replied "That is so gross, so weird, that's poking out, it shouldn't be like that", and Subject A immediately compared that reaction to when that friend was shown 2G1C - "I think she was more shocked looking at an outie labia than when she saw 2G1C! And I was like... 'seriously?!'”. My interviewee's obvious negative judgment of her friend's reaction shows that disgust has its right and wrong places, that there is a hierarchy of connections between certain materials and certain emotional responses, and that this hierarchy appeals to an absolute referential, where 2G1C must elicit more disgust than the image of "outie labia", to reassure that the person responding to it has the appropriate response.

Seen in this way, the laughter or the turning away evoked by the $2 \mathrm{G} 1 \mathrm{C}$ video seen in a social setting is not only the affective reaction to the disgust or offence (when applicable), but also the diffusion of the tension that comes from this sort of litmus test that simultaneously produces and pronounces a 'proper' sexual subject.

The materiality and chronicity of power relationships - and of technologically mediated moral operations - do not lend themselves to blanket statements about what $2 \mathrm{G} 1 \mathrm{C}$ 'is' or 'does', though. Several traits of what is presented here are also found in research on

\footnotetext{
2 "Outie" is slang for when the labia minora are bigger than the labia majora in the vulva, and thus can be seen without parting the labia majora. The interviewee used this expression originally in English.
} 
other 'extreme' videos, demonstrating how they, and the reactions to them, form a cultural nexus of expectations, 'proper' responses, symbolic power and cultural capital (Kennedy and Smith 2013). In fact, part of the inspiration for this essay came from a conversation between Susanna Paasonen and myself on her Facebook profile, where she reported that none of her then-current students had heard about $2 \mathrm{G} 1 \mathrm{C}$, to which I responded by saying that almost all of my interviewees had. Viral videos, as other memes, ebb and flow in ways that are complicated to trace - is this Finnish youths versus Portuguese youths?; Northern Europe versus Southern Europe?; a freak datapoint based on a non-representative sample? Whatever the case might be, I am not suggesting that lack of knowledge about $2 \mathrm{G} 1 \mathrm{C}$ is equivalent to more sexual liberty or less social modes of microphysically managing the 'proper' sexual self.

What I am noting here is that changing social mores might make the objects used for this Othering and disciplining change, and that sexual cultures less invested in controlling or disciplining the sexual at the microphysical level might make less use of these strategies, or might replace them with other modes of technologizing the subject. Notwithstanding the valid critiques to the idea of pornographication (Smith 2010), it is relevant to look into how and by which power relationships the processes of Othering are contested and continued, through the use of the 'extreme' and its affective intensity, in a world where access to different materials is not continuous, contiguous or homogenous, and where the same content is not received the same way in different cultural contexts.

\section{References}

Ahmed, Sara. 2014. The Cultural Politics of Emotion. 2. ed. Edinburgh: Edinburgh Univ. Press. 
Attwood, Feona. 2002. "Reading Porn: The Paradigm Shift in Pornography Research." Sexualities 5 (1): 91-105. doi:10.1177/1363460702005001005.

— . 2011. "The Paradigm Shift: Pornography Research, Sexualization and Extreme Images." Sociology Compass 5 (1): 13-22. doi:10.1111/j.17519020.2010.00356.x.

Declercq, Marie. 2017. “Dez Anos de ‘2 Girls 1 Cup', a Cagada Brasileira Mais Memorável Da Internet." Vice, May 31. https://www.vice.com/pt_br/article/dezanos-de-2-girls-1-cup-a-cagada-brasileira-mais-memoravel-da-internet.

Doorn, Niels van. 2010. “Keeping It Real.” Convergence: The International Journal of Research into New Media Technologies 16 (4): 411-30. doi:10.1177/1354856510375144.

Foucault, Michel. 1994a. História Da Sexualidade 1: A Vontade de Saber. Lisboa: Relógio d'Água.

——1994b. História Da Sexualidade 2: O Uso Dos Prazeres. Lisboa: Relógio d'Água.

_ 2000a. "Technologies of the Self." In The Essential Works of Michel Foucault, 1954-1984: Ethics, edited by Paul Rabinow, 1:223-51. Essential Works. London: Penguin.

- 2000b. "The Ethics of the Concern of the Self as a Practice of Freedom." In The Essential Works of Michel Foucault, 1954-1984: Ethics, edited by Paul Rabinow, 1:281-301. Essential Works. London: Penguin.

2013. Vigiar E Punir. Biblioteca de Teoria Política 9. Lisboa: Edições 70.

Jones, Steve, and Sharif Mowlabocus. 2009. "Hard Times and Rough Rides: The Legal and Ethical Impossibilities of Researching 'Shock' Pornographies.” Sexualities 12 (5): 613-28. doi:10.1177/1363460709340371.

Jones, Steven. 2009. "Horrorporn/Pornhorror: The Problematic Communities and Contexts of Online Shock Imagery." In Porn.Com: Making Sense of Online 
Pornography, edited by Feona Attwood, 123-37. Oxford: Peter Lang Publishing.

Kennedy, Julia, and Clarissa Smith. 2013. "His Soul Shatters at about 0.23: Spankwire, Self-Scaring, and Hyperbolic Shock.” In Controversial Images: Media Representations on the Edge, edited by Feona Attwood, Vincent Campbell, I.Q. Hunter, and Lockyer Sharon, 239-53. Basingstoke, UK: Palgrave Macmillan. http://repository.falmouth.ac.uk/298/.

Klee, Miles. 2017. “"2 Girls, 1 Cup': An Investigation Into the Web’s Shittiest Mystery.” MEL Magazine, May 15. https://melmagazine.com/2-girls-1-cup-aninvestigation-into-the-web-s-shittiest-mystery-1ae04c8fcb10.

Paasonen, Susanna. 2010. "Repetition and Hyperbole: The Gendered Choreographies of Heteroporn.” In Everyday Pornography, edited by Karen Boyle, 63-76. London; New York: Routledge.

—. 2011a. "Absolutely Disguting: Shock Sites, Extremity, and the Forbidden Fruit." In Carnal Resonance: Affect and Online Pornography, 207-49. Cambridge, Massachusetts; London, England: MIT Press.

_. 2011b. Carnal Resonance: Affect and Online Pornography. MIT Press.

Rubin, Gayle. 2007. "Thinking Sex: Notes for a Radical Theory of the Politics of Sexuality." In Culture, Society and Sexuality: A Reader, edited by Richard Parker and Peter Aggleton, 2nd ed. New York: Routledge.

Scarcelli, Cosimo Marco. 2015. “'It Is Disgusting, but ... ': Adolescent Girls' Relationship to Internet Pornography as Gender Performance.” Porn Studies 2 (2-3): 237-49. doi:10.1080/23268743.2015.1051914.

Smith, Clarissa. 2010. "Pornographication: A Discourse for All Seasons." International Journal of Media and Cultural Politics 6 (1): 103-8. doi:10.1386/macp.6.1.103/3. 
Webber, V. 2013. "Shades of Gay: Performance of Girl-on-Girl Pornography and Mobile Authenticities." Sexualities 16 (1-2): 217-35. doi:10.1177/1363460712471119.

Young, Madison. 2014. “Authenticity and Its Role within Feminist Pornography.” Porn Studies 1 (1-2): 186-88. doi:10.1080/23268743.2014.888250. 